\begin{tabular}{|c|c|c|}
\hline 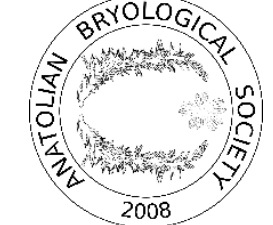 & $\begin{array}{l}\text { http://dergipark.gov.tr/anatolianbryology } \\
\text { Gökler. 2017. Anatolian Bryol. 3(1): 19-24 }\end{array}$ & $\begin{array}{c}\text { Anatolian Bryology } \\
\text { Anadolu Briyoloji Dergisi } \\
\text { Research Article } \\
\text { ISSN:2149-5920 Print } \\
\text { e-ISSN:2458-8474 Online }\end{array}$ \\
\hline
\end{tabular}

\title{
Contributions to the Liverworts Flora of Uşak Province
}

\author{
*İsa GÖKLER
}

Dokuz Eylül University, Faculty of Science, Department of Biology, 35390 Buca, Izmir, Turkey.

\begin{abstract}
This investigation presents the last position of liverworts of Uşak province. Plant specimens were collected from study areas between period of April 2007 and December 2011. As a result of identification studies, 19 liverworts species have been reported from this plant group belonging to the Marchantiophyta division. All of them are determined for the first time from Uşak province.
\end{abstract}

Key words: Liverworts, Flora, Uşak, Turkey.

\section{Uşak İli Ciğerotları Florasına Katkılar}

\section{$\ddot{O} \mathbf{z}$}

Bu çalışmada ciğerotlarının Uşak İli’ndeki son durumu araştırılmıştır. Bitki örnekleri Nisan 2007 ile Aralık 2011 tarihleri arasındaki dönemde araştırma bölgelerinden toplanmıştır. Tayin işlemleri sonucunda, Marchantiophyta bölümüne bağlı olan bu bitki grubundan 19 ciğerotu türü rapor edilmiş bulunmaktadır. Daha önce böyle bir çalışma olmadığından, bu türlerin tamamı Uşak İli için ilk kez belirlenmiş durumdadır.

Anahtar Kelimeler: Ciğerotları, Flora, Uşak, Türkiye.

\footnotetext{
* Corresponding author: isa.gokler@deu.edu.tr (C) 2017 All rights reserved / Tüm haklarl saklıdır.

To cite this article: Gökler I. 2017. Contributions to the Liverworts Flora. Anatolian Bryology. 3(1): 19-24.
} 


\section{Introduction}

Uşak is a province located in the western part of Turkey, bordered by Denizli to the south, Kütahya to the north, Manisa to the west, and Afyonkarahisar to the east (Figure 1). The climate of Uşak Province is Mediterraneanalpine and semidry terrestrial type. The annual average temperature is $12.3{ }^{\circ} \mathrm{C}$ and the annual rainfall is about $540 \mathrm{~mm}$. (UÇDR, 2011). The investigated area is a natural habitat for a number of trees and dominant forest plants, such as Pinus brutia Ten., P. nigra J.F. Arnold, Juniperus excelsa M. Bieb., J. oxycedrus L., J. foetidissima Willd., Quercus coccifera L., $Q$. ilex L. and Platanus orientalis L. (UÇDR, 2011). In the present study, many liverwort samples were collected from different localities of Uşak that had not been studied before.

\section{Materials and Methods}

The specimens of this study were collected from different localities within Uşak Province between 2007 and 2011 (Figure 1). The field studies were conducted mostly in autumn and spring, since during these periods the climatic conditions are most suitable for these plants.

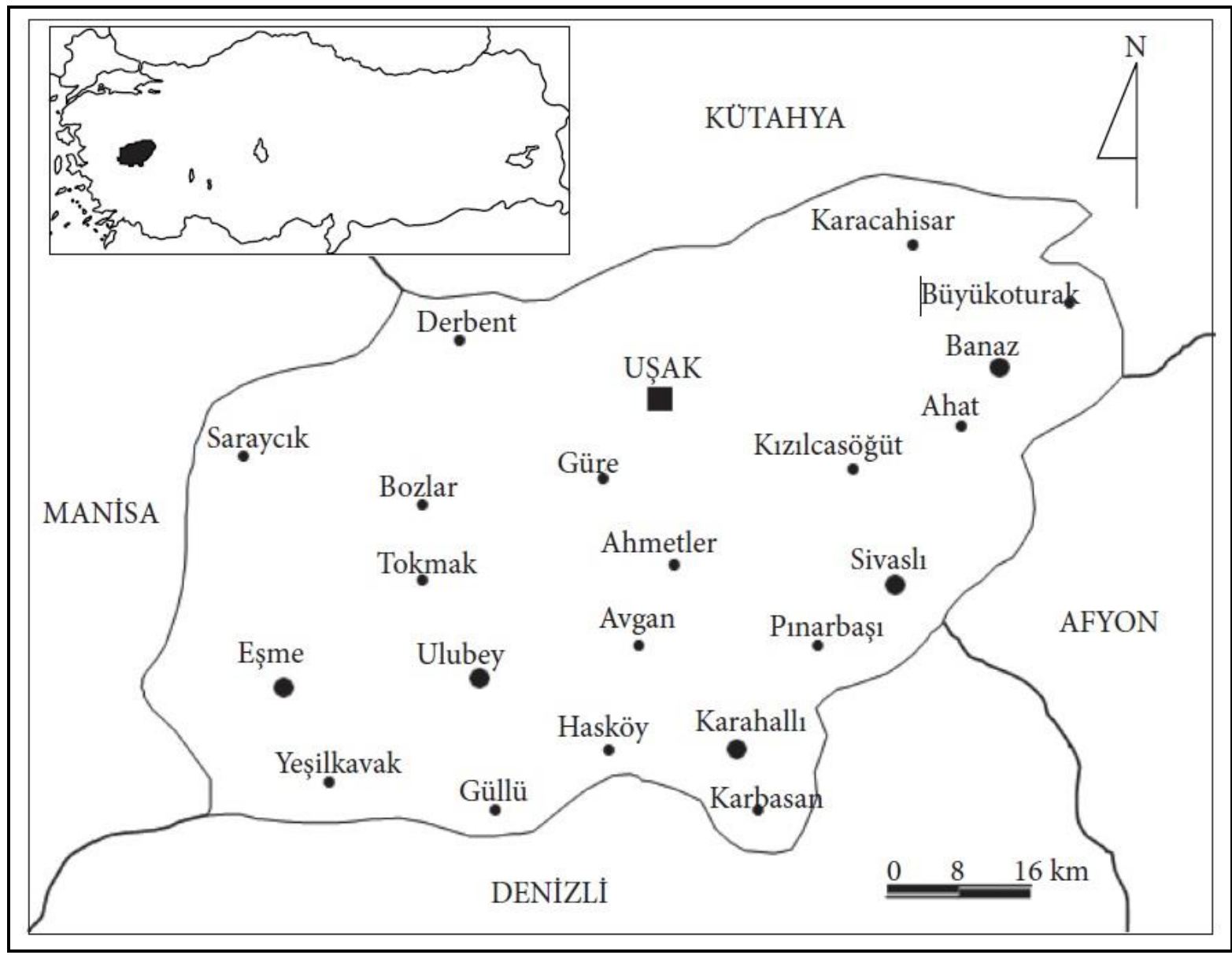

Figure 1. Map of the study area.

Specimens were thoroughly cleaned with water so as to remove the mud and see the color clearly, which is an important feature in their identification. The material was brought to the laboratory in small polyethylene bags and separated into two groups. These were then put into special herbarium envelopes without pressing. One group was left in the light, in a room with no air current while the other was these specimens were left fresh, for a study of their morphological and anatomical features. Determination of distributional areas (on the world and grid-squares of Turkey) and identification characteristics was carried out with the help of Henderson and Prentice (1969), Watson (1981), Smith (1996), Grolle and Long (2000), Söderström et al. (2002), Kürschner and Erdağ (2005), Özenoğlu Kiremit 
and Keçeli (2009) and some other relevant literature of Walther $(1967 ; 1970)$, Crundwell and Nyholm (1979), Gökler and Öztürk (1991; 1994), Gökler (1992; 2015) and Gökler and Özenoğlu (1999) conducted in the Aegean region of Turkey. The plant list is shown accordance with the system described by Goffinet, Buck and Shaw (2009). All the specimens were deposited in the Department of Biology, Faculty of Science, Dokuz Eylül University.

\section{Result and Discussion}

\section{Marchantiophyta \\ Marchantiopsida}

\section{Targioniaceae}

1. Targionia hypophylla $L$.

Banaz, Gürlek village, in pine forest on the rock, Gökler U5, 24.04.2008.

Eşme, Güllü town, Kavaklıdere district, on the rock, Gökler U16, 30.10.2010.

Ulubey, Avgan town, on the rock and bank of the Banaz stream, Gökler U27, 31.10.2010.

Distribution: Turkey (A1, A2, B6, B7, C11, C12, C13), Mediterranean Countries and Canada.

\section{Aytoniaceae}

2. Plagiochasma rupestre (R. et G. Forst.) Steph.

Eşme, Güllü town, Kavaklıdere district, on the rock, Gökler U17, 30.10.2010.

Distribution: Turkey (A2, A4, B6, B7, C11, C 12), Mediterranean Countries and Russia.

\section{Reboulia hemisphaerica (L.) Raddi}

Eşme, Güllü town, Kavaklıdere district, on the wet rock, Gökler U18, 30.10.2010.

Ulubey, Avgan town, on the rock and bank of the Banaz stream, Gökler U28, 31.10.2010.

Distribution: Turkey (A1, A2, A4, B6, B7, B8, C11, C12, C13), a cosmopolitan species all around the world.

\section{Conocephalaceae}

4. Conocephalum conicum (L.) Underw.

Banaz, Hamamboğazı district, on the wet stones and banks of stream, Gökler U6,

24.04.2008.

Banaz, Evrendede picnic area, near the stream bank, Gökler U13, 21.11.2008.

Uşak, Güre town, on the stream banks and humid rocks around the thermal spring, Gökler U15, 18.11.2009.

Distribution: Turkey (A1, A2, A3, A4, A5, B6, B8, C11, C12), Europe and North America.

\section{Lunulariaceae}

5. Lunularia cruciata (L.) Lindb.

Sivasl1-Uşak roadside, on the damp rocks and earth, Gökler U1, 03.04.2007.

Ulubey, entrance of Dumanli village, on the stream banks, Gökler U2, 03.04.2007.

Distribution: Turkey (A1, A2, A3, A4, A5, B6, B7, B9, C11, C12), Europe, Mediterranean Countries and Australia.

\section{Metzgeriaceae}

6. Metzgeria conjugata Lindb.

Ulubey, Avgan town, on bank of the Banaz stream, Gökler U29, 31.10.2010.

Karahall, Karbasan town, around the earth of stream, Gökler U36, 05.06.2011.

Distribution: Turkey (A1, A2, A3, A4, A5, B6, B7, C11, C13), Europe, Asia, South Africa, North America, Brazil and New Zeland.

\section{M. furcata (L.) Dum.}

Ulubey, entrance of Dumanli village, on the stream banks, Gökler U3, 03.04.2007.

Karahall1, Karbasan town, around the earth of stream, Gökler U37, 05.06.2011.

Distribution: Turkey (A1. A2, A3, A4, A5, B6, B7, C11, C12, C13), Europe, Asia, North America, Japan, Australia and New Zeland. 


\section{Jungermanniopsida \\ Pelliaceae \\ 8. Pellia endiviifolia (Dicks.) Dum.}

Uşak, around Subaşı Park, on the damp rocks and earth, Gökler U51, 06.06.2011.

Distribution: Turkey (A1. A2, A3, A4, A5, B6, B7, B9, C11, C12), Europe, Caucasia,

Mediterranean Countries, Japan, Korea, China, North America.

\section{P. epiphylla (L.) Corda}

Banaz, Hamamboğazı district, on the wet stream banks, Gökler U7, 24. 04. 2008.

Uşak, around Subaşı Park, on the damp rocks and earth, Gökler U53, 06.06.2011.

Distribution: Turkey (A1, A2, A3, A4, A5, B6, C11), Europe, North Africa, Asia and North America.

\section{Fossombroniaceae}

10. Fossombronia pusilla (L.) Nees

Sivasl1, entrance of Selçikler village, on the wet earth, Gökler U54, 06.06.2011.

Banaz, around Ahatköy, on the stream bank, Gökler U101, 22.11.2011.

Distribution: Turkey (A1, A2, A3, A4, B6, C11, C12), Europe, Mediterranean Countries, North and South Africa, North America and Chile.

\section{Lophocoleaceae}

11. Lophocolea bidentata (L.) Dum

Banaz, Evrendede picnic area, near the stream bank, Gökler U14, 21.11.2008,

Distribution: Turkey (A1, A2, A3, A4, A5, B6, B7, C11, C12), Europe, Asia, Africa, North America, Cuba and New Zeland.

12. L. heterophylla (Schrad.) Dum.

Banaz-Afyon road, $9 \mathrm{~km}$, on the bank of stream, Gökler U121, 23.11.2011.
Distribution: Turkey (A1, A2, A3, A4, A5, B6, B7), Europe, Russia, Japan, India, Tunisia and North America.

\section{Scapaniaceae}

13. Scapania undulata (L.)Dum.

Banaz, Hamamboğazı district, on the roots and trunks of Platanus orientalis L., Gökler U18, 18.11.2009.

Distribution: Turkey (A1, A2, A4, B6, C11), Europe and North America.

\section{Radulaceae \\ 14. Radula complanata (L.) Dum.}

Banaz, Evrendede picnic area, near the stream bank, on the tree trunks, Gökler U123,

23.11.2011.

Distribution: Turkey (A1, A2, A3, A4, A5, B6, B7, C11, C12, C13), Europe, North Africa, Asia and North America.

\section{Porellaceae}

15. Porella baueri (Schiffn.) C. Jens.

Uşak, Güre town, on the humid rocks around the thermal spring, Gökler U132, 14.12.2011.

Distribution: Turkey (B6, B7, C11), Europe.

16. P. cordaeana (Hüb.) Moore

Uşak, around Subaşı Park, on the damp rocks, Gökler U53, 06.06.2011.

Karahall1, Karbasan town entrance, on the humid rock and trunk of Platanus orientalis L., Gökler U40, 05.06.2011.

Distribution: Turkey (A1, A2, A3, A4, B6, B7, C11, C12, C13), Europe, Asia, Africa and America.

17. P. platyphylla (L.) Pfeiff.

Karahall1, Karbasan town entrance, on the humid rock and trunk of Platanus orientalis L., Gökler U42, 05.06.2011.

Banaz-Afyon road, $9 \mathrm{~km}$, on the damp rock of stream bed, Gökler U124, 23.11.2011. 
Distribution: Turkey (A1, A2, A3, A4, A5, B6, B7, B8, C11, C12, C13), Europe, Mediterranean Countries, North Africa and North America.

\section{Frullaniaceae}

18. Frullania dilatata (L.) Dum.

Eşme, Tokmak village, on the trunks of Quercus coccifera L., Gökler U20, 30.10.2010.

Banaz, around Ahatköy, on the tree trunks, Gökler U123, 22.11.2011.

Distribution: Turkey (A1, A2, A3, A4, A5, B6, C11, C12, C13), Europe, Asia and North Africa.

\section{Lejeuneaceae}

19. Lejeunea cavifolia (Ehrh.) Lindb.

Ulubey, Avgan town, on the humid rock of the Banaz stream, Gökler U32, 31.10.2010.

Distribution: Turkey (A1, A2, A3, A4, B6, B7, C11), Europe, Asia, North Africa and North America.

\section{References}

Crundwell C.C. Nyholm E. 1979. Some additions to the bryophyte flora of Turkey I. Hepaticae. Journal of Bryology. 10, 479-489.

Goffinet, B. Buck, W.R. Shaw, A.J. 2009. Morphology and classification of the Bryophyta. Cambridge University Press. Cambridge.

Gökler İ. 1992. Batı Anadolu Ciğerotları Üzerine Bir Araştırma. Doğa Türk Botanik Dergisi. 16:1, 18.

Gökler İ. 2015. Çanakkale İli Boynuzsu Otları ve Ciğerotları Üzerine Taksonomik ve Ekolojik Bir Araştırma. Anadolu Doğa Bilimleri Dergisi. 6:2, 35-43.

Gökler İ. Özenoğlu H. 1999. Kazdağı Milli Parkı ve Çevresi Ciğerotlarının Taksonomisi ve Ekolojisi. Ekoloji Çevre Dergisi. 30, 22-26.

Gökler İ. Öztürk M. 1991. Liverworts of Turkey and their position in Southwest Asia. Candollea. 46, 359-366.

Gökler İ. Öztürk M. 1994. Kütahya İli Ciğerotları Üzerinde Taksonomik ve Ekolojik Bir Araştırma. Ege Üniversitesi Fen Fakültesi Dergisi. 16:1, 1525-1529.

Grolle R. Long D.G. 2000. An Annotated Check-List of the Hepaticae and Anthocerotae of Europae and Macaronesia. Journal of Bryology. 22, 103-140.

Henderson D.M. Prentice H. 1969. Contributions to the bryophyte flora of Turkey. VIII. Notes from Royal Botanic Garden Edinburgh. 29, 235-262.

Kürschner H. Erdağ A. 2005. Bryophytes of Turkey: An Annotated Reference List of the Species with Synonyms from the Recent Literature and an Annotated List of Turkish Bryological Literature. Turkish Journal of Botany. 29, 95-154.

Özenoğlu Kiremit H. Keçeli T. 2009. An Annotated Check-list of the Hepaticae and Anthocerotae of Turkey. Cryptogamie Bryologie. 30:3, 343-356.

Smith A.E. 1996. The Liverworts of Britain and Ireland. Cambridge University Press. Cambridge.

Söderström L. Urmi E. Vana J. 2002. Distribution of Hepaticae and Anthocerotae in Europe and Macaronesia. Lindbergia. 27, 3-47.

Uşak İli Çevre Durum Raporu (UÇDR). 2011. Uşak Valiliği Çevre ve Şehircilik İl Müdürlügü. 
Walther K. 1967. Beitrage zur Moosflora Westanatoliens I. Mitteilungen aus dem Staatsinstitut für Allgemeine Botanik in Hamburg. 12, 129-186.

Walther K. 1970. Beitrage zur Moosflora Westanatoliens II. Mitteilungen aus dem Staatsinstitut für Allgemeine Botanik in Hamburg. 13, 167-180.

Watson E.V. 1981. British Mosses and Liverworts. Cambridge University Press. Cambridge. 